\title{
Avaliação da fidelidade genotípica por marcadores RAPDs de brotações de pereira (Pyrus communis $L$.) cv. Carrick, regeneradas in vitro ${ }^{I}$
}

\author{
Evaluation of the genotypic fidelity by RAPD markers of pear \\ shoots (Pyrus communis L.) cv. Carrick, in vitro regenerated
}

Alan Cristiano Erig ${ }^{2}$ Márcia Wulff Schuch ${ }^{3}$

RESUMO

\begin{abstract}
O objetivo deste trabalho foi avaliar a fidelidade genotípica de brotações de pereira (Pyrus communis L.) cultivar Carrick, regeneradas in vitro, utilizando marcadores RAPDs. O DNA genômico foi extraído de folhas oriundas das brotações de pereira regeneradas a partir de diferentes tratamentos e de plantas matrizes micropropagadas (planta controle), utilizando-se o protocolo descrito por FERREIRA \& GRATTAPAGLIA (1996). Para triagem dos primers foram utilizados os kits OPAN, OPA e OPF (Operon Technologies, Inc.) e, destes, foram escolhidos sete primers: OPAN-03, OPAN14, OPAN-15, OPAN-16, OPA-02, OPA-08 e OPF-04. A separação dos produtos da amplificação foi realizada através de eletroforese horizontal em gel de agarose 1,2\%, corado com brometo de etídio. Após a corrida, os géis foram visualizados sobre um transiluminador de luz ultravioleta $e$ fotografados com câmara Polaroid para registro dos dados. A ausência ou adição de uma ou mais bandas comparativamente ao padrão da planta matriz (planta controle) foi considerado variação somaclonal. Dos 66 fragmentos produzidos pelos sete primers, observou-se $100 \%$ de bandas monomórficas, indicando que nenhum dos primers utilizados detectou variação somaclonal nas brotações regeneradas.
\end{abstract}

Palavras-chave: pereira; variação somaclonal; marcadores moleculares; RAPD.

\section{ABSTRACT}

The aim of this work was to evaluate the genotypic fidelity of pear shoots (Pyrus communis L.) cultivar Carrick regenerated in vitro, using RAPD markers. Genomic DNA was extracted from leaves regenerated from pear shoots submitted to different treatments and from micropropagated matrix plants (control plant), using the protocol descripted by FERREIRA \& GRATTAPAGLIA (1996). For primer selection, the Kits OPAN,
OPA, and OPF (Operon Technologies, Inc.) were used. Seven primers were chosen: OPAN-03, OPAN-14, OPAN-15, OPAN16, OPA-02, OPA-08 and OPF-04. Amplified products were submitted to horizontal electrophoresis in $1.2 \%$ agarose gel, stained with ethidium bromide and visualized under UV light. The result was documented by using a Polaroid Camera. The absence or addition of bands, compared to the control plant pattern was considered somaclonal variation. The seven primers generated 66 fragments with 100\% monomorphics bands indicating that none of the primers used was able to detect somaclonal variation on the regenerated shoots.

Key words: pear; somaclonal variation; molecular markers; RAPD.

\section{INTRODUÇ̃̃O}

A pereira é uma frutífera que pertence a família Rosaceae, subfamília Pomoideae e ao gênero Pyrus. Sua fruta é uma das mais consumidas no mundo, sendo superada, apenas, pela maçã e pêssego (SIMONETTO \& GRELLMANN, 1999).

Em termos de classificação, as cultivares de pêra mais consumidas no mundo podem ser divididas em dois tipos: européias (Pyrus communis) e asiáticas (Pyrus pyrifolia var. Culta, Pyrus bretschneideri e Pyrus ussuriensis) (FAORO \& YASUNOBU, 2001). A cultivar Carrick, pertencente a espécie Pyrus communis L., é originária dos Estados Unidos, proveniente do cruzamento entre as cultivares Seckel x Garber (BROOKS \& OLMO, 1972).

\footnotetext{
${ }^{1}$ Parte da dissertação de mestrado do primeiro autor, apresentada ao Programa de Pós-graduação em Agronomia (PPGA), Faculdade de Agronomia Eliseu Maciel (FAEM), Universidade Federal de Pelotas (UFPel). Apoio FAPERGS.

${ }^{2}$ Engenheiro Agrônomo, Aluno do PPGA, área de concentração em Fruticultura de Clima Temperado, FAEM/UFPel, CP 354, 96.010-900, Pelotas, RS. E-mail: acerig@ufpel.tche.br. Autor para correspondência.

${ }^{3}$ Engenheiro Agrônomo, Doutora, Professora do Departamento de Fitotecnia, FAEM/UFPel, CP 354, 96.010-900, Pelotas, RS E-mail: marciaws@ufpel.tche.br
} 
A idéia de que a cultura de tecidos vegetais seria apenas uma técnica para propagar rapidamente plantas de maneira clonal e estável, não é apropriada (ILLG, 1990). Ocasionalmente variantes genéticos podem ocorrer a partir de qualquer forma de cultura de tecidos (LARKIN \& SCOWCROFT, 1981). Algumas mudanças são epigenéticas (LARKIN \& SCOWCROFT, 1981; AHUJA, 1987), não herdáveis, causadas pelas próprias condições de estresse fisiológico, às quais são submetidas tanto as células em cultura, quanto as plantas regeneradas in vitro (ILLG, 1990), enquanto outras são hereditárias e então denominadas de variação somaclonal (LARKIN \& SCOWCROFT, 1981; AHUJA, 1987).

A freqüência de mutantes não pode ser prevista e, aparentemente, diversos fatores podem afetar a natureza e a frequência da variação somaclonal, entre eles, o genótipo doador do explante, as condições de cultivo (ILLG, 1990), o tipo de explante, o meio de cultura (principalmente os reguladores de crescimento) (KLERK, 1990) e o estresse causado pelo próprio cultivo in vitro (CULLIS \& CLEARY, 1986).

Segundo LARKIN \& SCOWCROFT (1981), a variação somaclonal está presente na maioria das espécies estudadas e tem gerado efeito sobre inúmeras características, sendo as principais: alterações de padrão morfológico, de pigmentação, de crescimento, produção de alcalóides e mudanças na produção e habituação à auxinas e citocininas. OCHATT \& CASO (1986) verificaram que pereiras regeneradas a partir de protoplastos, diferiram de plantas modelo micropropagadas, tanto na morfologia das folhas como na capacidade de enraizamento.
$\mathrm{Na}$ atualidade, existem inúmeras técnicas de biologia molecular que podem ser usadas para detectar variabilidade genética ao nível de DNA. Uma estratégia para detectar variantes somaclonais é a utilização da técnica RAPD (KLERK, 1990; FERREIRA \& GRATTAPAGLIA, 1996). Segundo KARP (1989), a técnica chamada RAPD ("Random Amplified Polymorphic DNA") ou AP-PCR (“Arbitrarily primed PCR”) é útil no estudo do nível de variação genética em explantes cultivados in vitro em diferentes estádios de desenvolvimento, desde protoplastos até plantas regeneradas. LU et al. (1996) e HASHMI et al. (1997) mostraram a utilidade dos marcadores de RAPD no estabelecimento das bases genéticas da variação somaclonal em porta-enxerto de pessegueiro.

Considerando-se o exposto, o objetivo deste trabalho foi avaliar a fidelidade genotípica de brotações de pereira (Pyrus communis L.) cultivar Carrick, regeneradas in vitro, utilizando marcadores RAPDs.

\section{MATERIAL EMÉTODOS}

O trabalho foi realizado no Laboratório de Cultura de Células e Tecidos de Plantas, Departamento de Botânica do Instituto de Biologia, da Universidade Federal de Pelotas, Pelotas, RS.

Para avaliação da fidelidade genotípica, foram utilizadas folhas oriundas das brotações de pereira regeneradas a partir de diferentes tratamentos e de plantas matrizes micropropagadas (planta controle) (Tabela 1). Para cada tratamento que apresentou regeneração de brotações, foram analisadas duas

Tabela 1 - Identificação do tratamento e origem das brotações regeneradas fonte do material vegetal utilizado na avaliação da fidelidade genotípica de pereira, cv. Carrick. Pelotas, RS, 2002.

\begin{tabular}{|c|c|c|c|}
\hline \multirow{2}{*}{$\begin{array}{l}\text { Identificação } \\
\text { do tratamento }\end{array}$} & \multicolumn{3}{|c|}{ Origem das brotações regeneradas } \\
\hline & Tipo de explante & $\begin{array}{l}\text { Tempo de permanência em meio de } \\
\text { indução (dias) }\end{array}$ & $\begin{array}{c}\text { Concentração de TDZ no meio de } \\
\text { proliferação }(\mu \mathrm{M})\end{array}$ \\
\hline Mtz. & & Planta Matriz & \\
\hline $\mathrm{T} 1$ & ápice caulinar & 0 & 8,88 \\
\hline $\mathrm{T} 2$ & ápice caulinar & 0 & 13,32 \\
\hline $\mathrm{T} 5$ & entrenó & 0 & 8,88 \\
\hline T6 & entrenó & 0 & 13,32 \\
\hline $\mathrm{T} 7$ & ápice caulinar & 10 & 8,88 \\
\hline T8 & ápice caulinar & 10 & 13,32 \\
\hline T11 & entrenó & 10 & 8,88 \\
\hline T12 & entrenó & 10 & 13,32 \\
\hline T13 & ápice caulinar & 20 & 8,88 \\
\hline T14 & ápice caulinar & 20 & 13,32 \\
\hline T17 & entrenó & 20 & 8,88 \\
\hline T18 & entrenó & 20 & 13,32 \\
\hline T19 & ápice caulinar & 30 & 8,88 \\
\hline $\mathrm{T} 20$ & ápice caulinar & 30 & 13,32 \\
\hline $\mathrm{T} 25$ & ápice caulinar & 40 & 8,88 \\
\hline T26 & ápice caulinar & 40 & 13,32 \\
\hline
\end{tabular}


amostras de 100 a 200mg, compostas pela mistura das folhas das brotações regeneradas no tratamento. Para a planta controle também analisaram-se duas amostras de 100 a $200 \mathrm{mg}$ de folhas.

O DNA genômico foi extraído de tecidos foliares, utilizando-se o protocolo descrito por FERREIRA \& GRATTAPAGLIA (1996). Ele foi quantificado através de espectrofotômetro Pharmacia Biotech - Ultrospec 2000, com diluição 1:50.

Para triagem dos primers - oligonucleotídeos iniciadores - foram utilizados os kits OPAN, OPA e OPF (Operon Technologies, Inc.) (Figuras 1 e 2). Destes, foram escolhidos sete primers, que apresentaram as melhores bandas, mais nítidas e bem definidas: OPAN03, OPAN-14, OPAN-15, OPAN-16, OPA-02, OPA-08 e OPF-04. Para a escolha dos primers foi utilizado DNA extraído de uma planta matriz micropropagada (planta controle).

As reações de PCR foram realizadas em volume de $25 \mu \mathrm{L}$ para cada amostra de DNA. As reações continham $2,5 \mu \mathrm{L}$ de tampão de reação $10 \mathrm{X}(500 \mathrm{mM}$ de $\mathrm{KCl} ; 15 \mathrm{mM}$ de $\mathrm{MgCl}_{2}$ e $100 \mathrm{mM}$ de Tris- $\left.\mathrm{HCl} \mathrm{pH} 9,0\right)$, $2 \mu \mathrm{L}$ de dNTPs Mix (contendo 2,5mM de cada dNTP), 30 ng de primer, $10,1 \mu \mathrm{L}$ de água ultra pura estéril, 40ng do DNA extraído, 2 unidades de Taq DNA polimerase e uma gota de óleo mineral.

A amplificação foi realizada num termociclador programável PTC-100 (MJ Research, Inc.) em 40 ciclos repetidos de 1 minuto a $92^{\circ} \mathrm{C}$ (desnaturação), 1 minuto a $35^{\circ} \mathrm{C}$ (anelamento do primer),

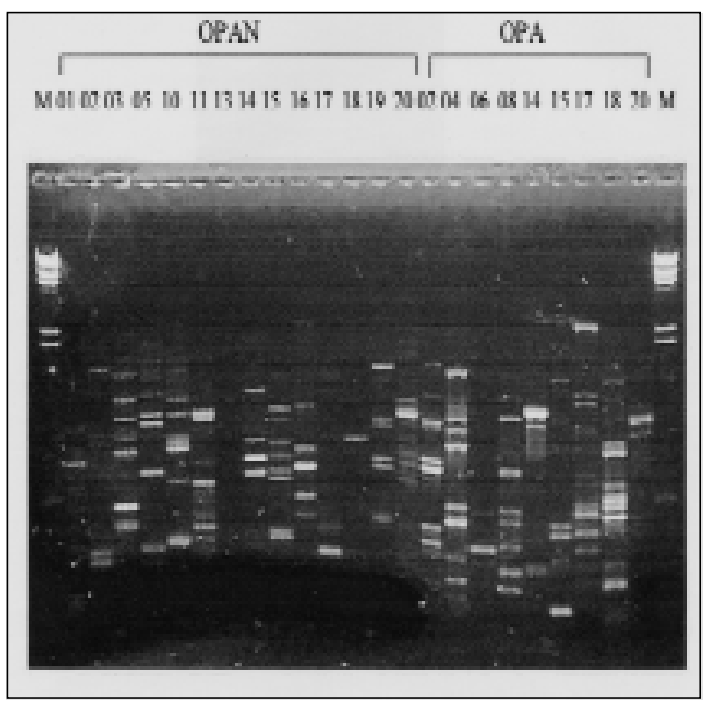

Figura 1 - Bandas RAPD de pereira, cv. Carrick, utilizando-se diferentes primers dos kits OPAN e OPA (Operon Technologies, Inc.). $\mathrm{M}=$ DNA do Fago $\lambda$. Pelotas, RS, 2002.

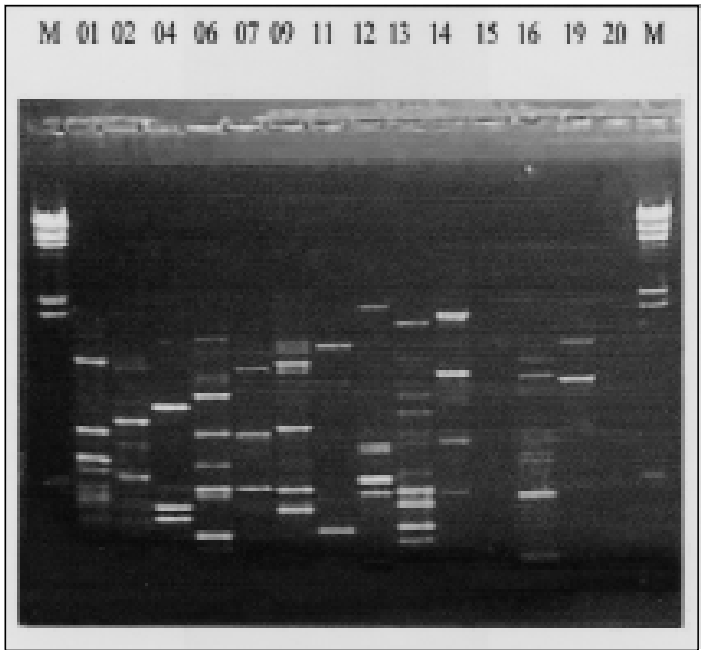

Figura 2 - Bandas RAPD de pereira, cv. Carrick, utilizando-se diferentes primers do kit OPF (Operon Technologies, Inc.). $\mathrm{M}=\mathrm{DNA}$ do Fago $\lambda ; 01$ à $20=$ primers utilizados. Pelotas, RS, 2002.

2 minutos a $72^{\circ} \mathrm{C}$ (extensão pela Taq DNA polimerase e incorporação de nucleotídeos). Após os 40 ciclos, foi realizado um passo final de extensão de 5 minutos a $72^{\circ} \mathrm{C}$, para finalização dos produtos amplificados. Ao término da reação de PCR, o termociclador foi programado para manter a temperatura a $4^{\circ} \mathrm{C}$ por tempo indefinido.

A separação dos produtos da amplificação foi realizada através de eletroforese horizontal em gel de agarose $1,2 \%$, corado com brometo de etídio (usaram-se $6 \mu \mathrm{L}$ de uma solução $10 \mathrm{mg} \mathrm{mL}^{-1}$ para um gel de $120 \mathrm{~mL})$. O desenvolvimento da eletroforese foi feita com o gel submerso em tampão TBE $0,5 \mathrm{X}$ (TBE $5 \mathrm{X}$ $1000 \mathrm{~mL}^{-1}$ : Tris Base $0,45 \mathrm{M}$; Ácido Bórico $0,45 \mathrm{M} ; 20 \mathrm{~mL}$ EDTA 0,5M pH 8,0), o mesmo utilizado no preparo do gel. A fonte de energia usada foi o Modelo 250 (Gibco BRL-Life Technologies) a 90 Volts.

Cada poço do gel foi carregado com $12 \mu \mathrm{L}$ da reação, acrescido de $5 \mu \mathrm{L}$ de tampão de carregamento $\left(0,4 \mathrm{~g} \cdot \mathrm{mL}^{-1}\right.$ de sacarose; $2,5 \mathrm{mg} \mathrm{mL}^{-1}$ de azul de bromofenol em tampão TE). Utilizou-se como marcador de peso molecular o DNA do Fago $\lambda$ clivado com Hind III. Aplicou-se $5 \mu \mathrm{L}$ do DNA do Fago $\lambda$ e $3 \mu \mathrm{L}$ do tampão de carregamento no início e no fim de cada gel.

Após a corrida, os géis foram visualizados sobre um transiluminador de luz ultravioleta e fotografados com câmara Polaroid para registro dos dados. A ausência ou adição de uma ou mais bandas comparativamente ao padrão da planta matriz (planta controle) foi considerado variação somaclonal. 


\section{RESULTADOS E DISCUSSÃO}

Os sete primers utilizados na avaliação da fidelidade genotípica das brotações regeneradas de pereira cv. Carrick, produziram 66 fragmentos, com o número de bandas produzidas por primer variando de 7 (OPA-02) até 13 (OPAN-03), com uma média de 9,4 fragmentos por primer (Tabela 2 ). BOGANI et al. (1995), trabalhando com regenerantes de tomate, encontraram 58 fragmentos de DNA quando da utilização de 10 primers. WENDT (1999) obteve 70 fragmentos utilizando 10 primers na análise molecular de clones de batata, com o número de bandas produzidas por primer variando de 4 até 10 , com média de 7 fragmentos por primer. Em mandioca foi encontrado uma média de 9 bandas por primer (COLOMBO et al., 1998). HASHMI et al. (1997) encontraram uma média de 12 bandas por primer, trabalhando com pessegueiro. DETTORI \& PALOMBI (2000) utilizaram 11 primers, na avaliação da variabilidade genética de Feijoa sellowiana, e obtiveram, em média, 12 bandas por primer. Entretanto, deve-se considerar que as espécies utilizadas nos trabalhos foram diferentes.

Dos 66 fragmentos produzidos neste trabalho, observou-se $100 \%$ de bandas monomórficas, indicando que, nenhum dos sete primers utilizados detectou variação somaclonal nas brotações regeneradas de pereira cv. Carrick, quando comparadas com o padrão da planta matriz (planta controle) (Figura 3).

Este resultado pode ser justificado pelo fato de as brotações regeneradas terem se originado a partir de tecidos do explante, ou seja, via regeneração direta. As plantas regeneradas via regeneração direta são mais estáveis que aquelas obtidas a partir de calos (KAMENICKÀ \& RYPÁK, 1989) com menor risco de quimeras e variação somaclonal (DIAMATO, 1977).

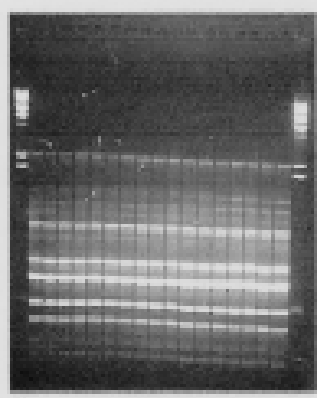

(d)

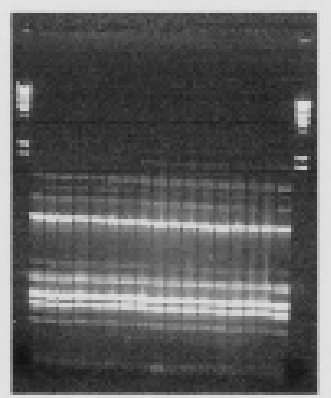

(g)

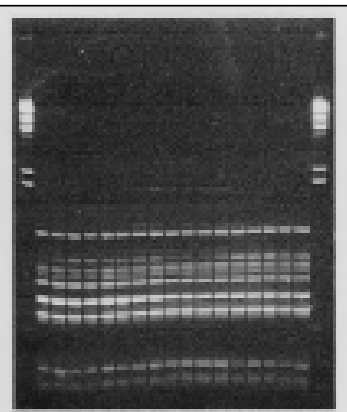

(b)

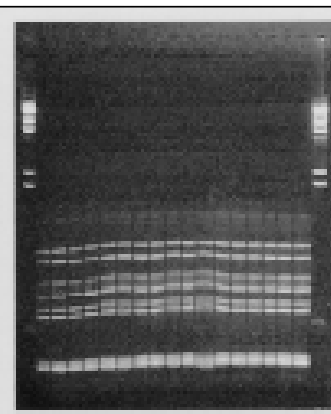

(c)

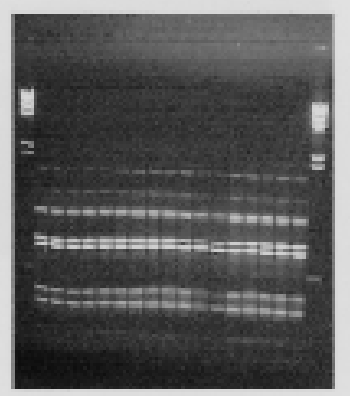

(c)

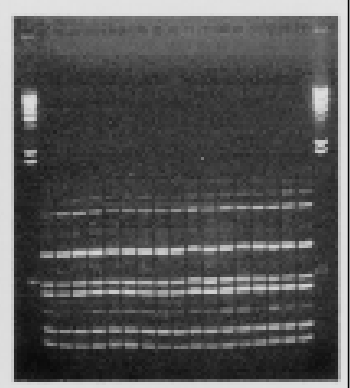

(f)
Figura 3 - RAPDs de amostras de brotações regeneradas de pereira cv. Carrick, resolvidos em géis de agarose (1,2\%): (a) primer OPAN-03; (b) primer OPAN-14; (c) primer OPAN-15; (d) primer OPAN-16; (e) primer OPA-02; (f) primer OPA-08 e (g) primer OPF-04 (Operon Technologies, Inc.). Pelotas, RS, 2002.

Segundo ILLG (1990), plantas regeneradas de cultura de tecidos via formação de calos comumente apresentam fenótipos variantes.

HASHMI et al. (1997), analisando variantes somaclonais derivados de cultura de calos embrionários de pêssego, encontraram $29 \%$ dos fragmentos polimórficos. Já SHOYAMA et al. (1997), estudando as plântulas regeneradas via embriogênese somática de Panax notoginseng, constataram homogeneidade genética, quando comparadas entre si e quando comparadas com a planta original. 
Tabela 2 - Número de bandas produzidas por primer na avaliação da fidelidade genotípica por marcadores RAPDs, das brotações regeneradas de pereira cv. Carrick. Pelotas, RS, 2002.

\begin{tabular}{lc}
\hline Primer & Número de bandas produzidas por primer \\
\hline OPAN-03 & 13 \\
OPAN-14 & 10 \\
OPAN-15 & 8 \\
OPAN-16 & 11 \\
OPA-02 & 7 \\
OPA-08 & 8 \\
OPF-04 & 9 \\
Média & 9,4 \\
\hline
\end{tabular}

VIRSCEK et al. (1999) utilizaram 25 primers de RAPD para determinar a variação genética em 39 e 38 regenerantes de macieira das cultivares Golden Delicious Bovey e Goldspur, respectivamente, e concluíram que a técnica de regeneração induziu uma alta variação genética nestas cultivares.

CABONI et al. (2000) estudaram a variação somaclonal em regenerantes de macieira (Malus pumila) cv. Jork-9 e, de pereira (Pyrus communis) clone ISF61 pela análise RAPD. Neste trabalho, foram analisados 30 regenerantes de cada espécie obtidos a partir de folhas ou ápices caulinares, usando-se 20 primers. A análise revelou pouco polimorfismo nos clones regenerados a partir de folhas, enquanto nenhuma variação foi detectada nos clones regenerados de ápices caulinares.

KARP (1995) relata que certos genótipos parecem ser geneticamente mais instáveis in vitro do que outros. Isto evidencia que a variação somaclonal também é dependente do genótipo.

\section{CONCLUSÃO}

Os resultados permitem concluir que não foi possível detectar variação somaclonal nas brotações de pereira regeneradas in vitro, quando comparadas com o padrão da planta matriz, por meio dos primers utilizados na técnica de RAPD.

\section{REFERÊNCIASBIBLIOGRÁFICAS}

AHUJA, M.R. Somaclonal variation. In: BONGA, J.M.; DURZAN, D. J. (eds). Cell and tissue culture in forestry. Dordrecht: Martinus Nijhoff, 1987. p.272-285.

BOGANI, P. et al. Genome flux in tomato auto and auxotrophic cell clones cultured in different auxin/cytokinin equilibria. I. DNA multiplicity and methylation levels. Genome, Ottawa, v.38, p.902-912, 1995.

BROOKS, R. M.; OLMO, H. P. Register of new fruit \& nut varieties. 2.ed. Berkeley : University of California, 1972.
CABONI, E. et al. Somaclonal variation induced by adventitious shoot regeneration in pear and apple. Acta Horticulturae, The Hague, n.530, p.195-201, 2000.

COLOMBO, C. et al. Genetic diversity characterization of cassava cultivars (Manihot esculenta Crantz). I) RAPD markers. Genetics and Molecular Biology, Ribeirão Preto, v.21, n.1, p.105-113, 1998.

CULLIS, C.A.; CLEARY, W. DNA Variation in flax tissue culture. Canadian Journal of Genetics and Cytology, Ottawa, v.28, p.247-251, 1986

DETTORI, M.T.; PALOMBI, M.A. Identification of Feijoa sellowiana Berg accessions by RAPD markers. Scientia Horticulturae, Amsterdam, v.86, p.279-290, 2000.

DIAMATO, F. Cytogenetics of differentiation in tissue and cell culture. In: REINERT, J.; BAJAJ, Y.P.S. (eds). Applied and fundamental aspects of plant cell, tissue and organ culture. New York : Springer-Verlag, 1977. p.343-464.

FAORO, I.D.; YASUNOBU, Y. Cultivares e porta-enxertos de pereira japonesa. JICA Boletim Informativo, Caçador, n.3, p. 7, 2001.

FERREIRA, M.E.; GRATTAPAGLIA, D. Introdução ao uso de marcadores moleculares em análise genética. Brasília: Embrapa - CENARGEN, 1996. 220p.

HASHMI, G. et al. RAPD analysis of variation variants derived from embryo callus cultures of peach. Plant Cell Reports, New York, v.16, p.624-627, 1997.

ILLG, R.D. Variação somaclonal. In: TORRES, A.C.; CALDAS, L.S. (eds). Técnicas e aplicações da cultura de tecidos de plantas. Brasília : ABCTP / Embrapa - CNPH, 1990. p.287295.

KAMENICKÀ, A.; RYPÁK, M. The regeneration of Actinidia chinensis $\mathrm{Pl}$. cultured in vitro. Polnohospodarvo, v. 35 , n.9, p.811-818, 1989. (Base de dados na Internet - CAB).

KARP, A. Can genetic instability be controlled in plant tissue culture. Newsletter International Association of Plant Tissue Culture, Calgary, v.58, p.2-11, 1989.

KARP, S. Somaclonal variation as a tool for crop improvement. Euphytica, Wageningen, v.85, p.295-302, 1995.

KLERK, G.J. How to measure somaclonal variation. Acta Botanica Neerlandica, Amsterdam, v.38, n.2, p.129-144, 1990

LARKIN, P.J.; SCOWCROFT, W.R. Somaclonal variation: a novel source of variability from cell cultures for plant improvement. Theoretical and Applied Genetics, New York, v.60, p.197-214, 1981

LU, Z.X.; REIGHARD, G.L.; BAIRD, W.V. Identification of peach rootstock cultivars by RAPD markers. HortScience, Alexandria, v.31, n.1, p.127-129, 1996.

OCHATT, S.J.; CASO, O.H. Shoot regeneration from leaf mesophyll protoplasts of wild pear (Pyrus communis var. pyraster L.). Journal of Plant Physiology, Stuttgart, v.122, p. $243-249,1986$

Ciência Rural, v. 33, n. 3, mai-jun, 2003. 
SHOYAMA, Y. et al. Micropropagation of Panax $\boldsymbol{n}$ otoginseng de cultivares de pereira na região serrana do Rio Grande do Sul. Boletim FEPAGRO, Porto Alegre, n.9, 1999. $28 \mathrm{p}$

VIRSCEK, M. M.; BOHANEC, B.; JAVORNIK, B. Adventitious shoot regeneration from apple leaves - Optimisation of the protocol and assessment of genetic variation among regenerants. Phyton
Annales Rei Botanicae, Horn, v.39, n.1, p.61-70, 1999.

WENDT, S.N. Obtenção e caracterização molecular de plantas de batata (Solanum tuberosum L.) cv. Macaca a partir de explantes irradiados com raios gama $\left({ }^{60} \mathrm{Co}\right)$. 1999. 66f. Dissertação (Mestrado em Agronomia Fitomelhoramento) - Faculdade de Agronomia Eliseu Maciel, UFPel, 1999. 